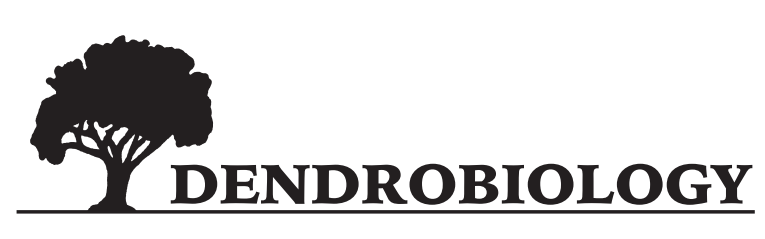

2014, vol. 71, 49-58

http://dx.doi.org/10.12657/denbio.071.005

Tomasz H. Szymura, Magdalena Szymura, Marek Pietrzak

\title{
Influence of land relief and soil properties on stand structure of overgrown oak forests of coppice origin with Sorbus torminalis
}

\author{
Received: 18 March 2013; Accepted 06 June 2013
}

\begin{abstract}
Traditional forest management as coppicing and coppicing-with-standard are recently considered as beneficial for biodiversity in woodlands. Cessation of coppicing leads to changes in stand structure and often loss of biodiversity. In contemporary Polish forestry coppicing is not applied, however some stands of coppice origin persist in Silesia until present. The overgrown coppice oak forests that cover the southern slopes at the foothills of the Sudetes Mountains (Silesia, Central Europe) are considered to be Euro-Siberian steppic woods with a Quercus sp. habitat (9110): a priority habitat in the European Union, according to the Natura 2000 system. They support one of the largest populations of wild service tree (Sorbus torminalis Crantz) in Poland. In this study we investigated the relation of stand structure and trees parameters with environmental variables. The results showed considerable variability of stand volume, tree density and stems' size correlated mostly with soil texture, but not nutrient content. We attributed it to soil dryness which seems to be the crucial factor controlling growth of trees. The natural regeneration of trees concentrated mostly on non-exposed sites on less acidic soils, but seedlings of wild service tree were present almost exclusively on most insolated sites, with shallow acidic soils. However, the regeneration of trees in sapling stage was restrained by browsing. Results suggest that maintaining of Sorbus torminalis requires protection against browsing, and some kind of active management is necessary to retain the observed stand structure with high proportion of wild service trees in stands on more fertile soils.
\end{abstract}

Additional key words: Sorbus torminalis, regeneration niche, edaphic dryness, Euro-Siberian steppic woods with a Quercus sp, succession, historical forest management.

Addresses: T.H. Szymura, M. Pietrzak - Department of Ecology, Biogeochemistry and Environmental Protection, University of Wroclaw. pl Maksa Borna 9, 50-328 Wrocław, e-mail: tszymura@biol.uni.wroc.pl M. Szymura - Department of Agroecosystems and Green Areas Management, Wrocław University of Environmental and Life Sciences. pl. Grunwaldzki 24A , 53-363 Wrocław

\section{Introduction}

Most of Central European woods are recently managed as high forests, that is they consist of single-stemmed trees. Those trees are of generative ori- gin, germinated from seeds if natural regeneration is applied or planted as seedlings when artificial regeneration is used. Period of rotation between establishment and cutting of such individuals is relatively long - about 100 years and more. However, until early 
1950s, forests managed by coppicing were widespread in Central Europe. In this system stems of trees were of vegetative origin, coming from living stumps, socalled stools. This kind of management was simple to organize, easy to apply even in very small, private forests. If quite short rotation was applied, sometimes 14-20 years, it was profitable as producing large amount of small size fire wood, or for production of bark for tanning purposes. Among clusters of short stems, originating from one stool, scattered, single, tall trees of generative origin could be planted. This system, called coppice-with-standard, could provide also some amount of large timber. These two-coppicing and coppicing-with-standard traditional kinds of management gradually disappeared from Central Europe due to their diminishing economic efficiency (Matthews 2001, Ellenberg 2009).

Quite unexpectedly, this transition brought a lot of ecological changes in forest ecosystems services, among others it results in the loss of biodiversity. Coppicing, as a kind of disturbance, was proved as beneficial for light demanding species of animals and forest floor plants. Those species gradually start to disappear in woods managed as high forest with long rotation period (Decocq et all 2005, Van Calster et all 2007, Verheyen et all 2012 ). Abandoning of coppicing in oak forests led to expansion of stronger competitive tree species, with denser canopy and easily decomposed litter as e.g. ash, hornbeam, sycamore (Hofmeister et all 2004, Collet et all 2008, Verheyen et all 2012). The cessation of coppice-with-standard system also resulted in rapid diminution of wild service tree (Sorbus torminalis) population in Central Europe (Müller et all 2000). This species rare in Central Europe, protected in Poland, was often planted as standard tree in coppice-with-standard systems as producing valuable timber (Müller et all 2000). Moreover, due to its high ability to propagate by suckers this species also tolerated the coppicing well. Currently the coppicing aroused the interest of scientists again, as a system which could support a high level of biodiversity. The abandoning of coppicing, considered as natural experiment, also gives opportunity to study succession processes and increase the knowledge about ecology of trees and forest communities. However, studies in this field are rare and concentrate on the lowlands of western part of Europe (Hédl et all 2010). Also the ecology of wild service tree, including its relation with coppicing, is recently investigated throughout central Europe in order to gain better knowledge about ecology of this species and to elaborate efficient method of its conservation (Müller et all 2000, Maděra et all 2012, Maděra et all 2013).

In the territory of contemporary Poland, coppicing and coppicing-with-standard have never been common management systems. Only in Silesia, where coppicing has had a long tradition, it has been quite frequently applied method. Area of coppiced and coppiced-with-standard forests in Silesia was about 16,000 ha at the turn of the $20^{\text {th }}$ century. Nowadays, coppicing is not applied in Polish forestry, however in Sudety Mountains foothills about 3,000 ha of oak forests of coppice origin persist until today (Szymura 2012). The overgrown (that has not been cut for about 70 years) oak forests of coppice origin mostly cover slopes with southern exposition on shallow soils. Some of these stands are considered as Euro-Siberian steppic woods with Quercus sp. (91I0)- a priority habitat in the European Union, according to the Natura 2000 system. One of the largest concentration of wild service trees in Poland occurrs also in these stands (Bednorz 2007), where it co-creates a rare in Poland forest community Sorbo torminalisQuercetum (Kwiatkowski 2003).

The tree stand structure and ecology of oak forest of coppice origin have never been a subject of study in Poland. There is also lack of knowledge about structure of population of wild service tree in such exceptional, in the scale of Poland, ecosystems. It could be expected that in the stands, similarly to other abandoned coppices, the proportion of mesic, shade tolerate tree species as ash, sycamore or hornbeam increases. In studied sites the environmental gradients in soil resources, thermal conditions and light availability significantly influence forest floor vegetation. In most exposed sites, with thin soil layer the conditions are harsh and restrict the vegetation (Szymura and Szymura 2011, 2013). Therefore, we hypothesize that the environmental factors also affect the stand structure, especially causing the differentiation in regeneration niches of tree species. We expect that young individuals of shade tolerant species will be more numerous in more productive sites, however the magnitude of effects of environmental traits on overall stand structure and distribution of particular species is unknown. It is also unknown which ecophisiological factors are limiting in studied ecosystems: it could be moisture, soil fertility, light availability or/and thermal conditions. Moreover, the observed effect of the environmental traits could have be modified by past forest management and biotic interaction e.g browsing by ungulates (Chytrý and Danihelka 1993 Cermák and Mkrva 2006). Therefore, we did not decide to state more detailed hypothesis on testing, and we consider this study in large extend, as exploratory. As a model object for overgrown coppice oak forest with Sorbus torminalis in Poland we have chosen two largest reserves which protected such stands: Grobla and Wąwóz Lipa. 


\section{Materials and methods}

\section{Study site}

The study was performed in Lower Silesia (SW Poland), in Sudety Mountains foothills, in two largest reserves of protected forest of coppice origin in Poland: "Grobla" (50 59' 5" N, $16^{\circ} 6^{\prime} 5^{\circ}$ " E, area 76 ha) and "Wąwóz Lipa" (50 58' 51" N, 16 2' 39" E, area $52 \mathrm{ha}$ ). They are situated ca. $3 \mathrm{~km}$ from each other. The geological settings consist of greenschists-metamorphic basalt rocks. The average annual temperature is $7.0^{\circ} \mathrm{C}$ (July $16.1^{\circ} \mathrm{C}$, January $-2.6^{\circ} \mathrm{C}$ ), average annual precipitation is $801 \mathrm{~mm}$ with a maximum in July-August and the average length of the growing season is 200-220 days (Kwiatkowski 2001).

The analyzed stand grows on the uplands, slope and base of the plateau elevated above river valley. The altitude of the uplands is about $380-410$ m.a.s.l and of the base about 330 m.a.s.l. The slopes forms a kind of continuous scarp in south and south-western directions and are interrupted by a few erosion gorges. Rock outcrops, as well as stone runs are also present on the slopes. As an example of land relief, the reserve "Grobla" is shown in Figure 1.

The study site has been continuously forested since at least 1748 . In $19^{\text {th }}$ century studied stands were managed as coppice in order to produce high quality oak bark (so-called mirror bark) for tanning purposes. Short rotation period of ca. 14-20 years was applied. At the end of $19^{\text {th }}$ century the production of oak bark became uneconomical and such stands were gradually transformed into high forest by applying coppice-with-standards method. The conversion was typically carried out by removing the oldest, low productive stools and planting seedlings subsequently managed as high trees. The conversion was concentrated on flatter areas with thicker soil layer, where productivity of stands was higher. It is known that oaks were planted as standard trees, however it is

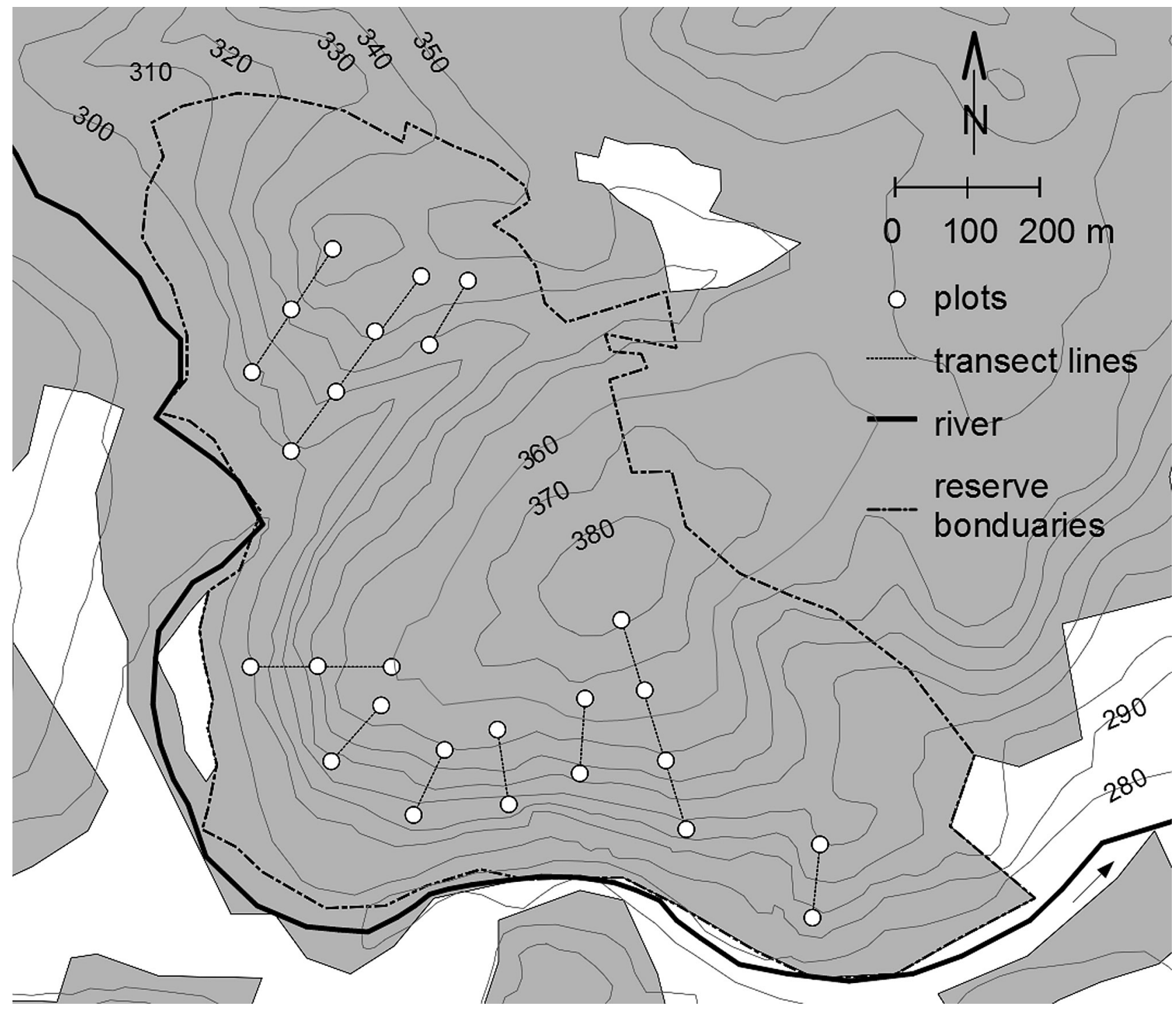

Fig. 1. Reserve "Nad Groblą" as an example of land relief and sampling plots arrangement 
highly probable that Sorbus torminalis were also planted. It was a typical system at that time in Germany, but we do not have any written sources confirming the use of wild service tree in Silesia. In some places with deeper soil also plantations of coniferous trees were introduced after clear-cutting of oaks stands. After the Second World War coppicing was no longer applied. Some multi-stem individuals were singled, moreover in small patches the oak stand was removed and coniferous plantation was introduced. Nevertheless, a considerable part remained untouched due to low productivity of the sites. According to forest documentation the age of stems is estimated at 78-105 years, however the data may not be very detailed. The age of stools is unknown, most probably it varies since the oldest, low productive ones were gradually replaced by planting new plants (Szymura 2012).

Oak forests occur on the convex parts of the slope, whereas the concave forms of the slope, in gorges, are covered by ravine forest with lime and sycamore trees. A strip of alluvial forest occurs at the bottom of the slope, along watercourses. The oak forests were classified as: Central European acidophilous oak forests (Calamagrostio arundinaceae-Quercetum), submontane acidophilous oak forests (Luzulo luzuloidis-Quercetum), including its thermophilous form L.Q. genistetosum tinctoriae. Patches of submontane thermophilous oak forest with wild service trees (Sorbus torminalis) Sorbo torminalis-Quercetum were also reported in the study area (Kwiatkowski 2001, Kwiatkowski 2003). The most frequent plant species in forest floor were: Calamagrostis arundinacea, Convallaria majalis, Hieracium murorum, Galium schultesii and Poa nemoralis. Among species considered as diagnostic for Sorbo torminalis-Quercetum most frequent were Cephalanthera longifolia and Campanula persicifolia (Szymura and Szymura 2013).

\section{Methods}

A set of transects, extending from the base of slope to the top of the uplands on convex parts of the slope were arranged. The concave part of slopes (gorges) were not sampled because they were covered by ravine forests. Patches of artificial coniferous monocultures were also omitted. Sampling plots were placed on the transects at the intervals of $100 \mathrm{~m}-26$ plots in "Grobla" and 24 in "Lipa" reserves. The sampling plots were circular with an area of $250 \mathrm{~m}^{2}$. There were 50 plots in total. Inside each sampling plot three subplots were additionally established at compass directions: $0^{\circ}, 120^{\circ}$ and $240^{\circ}$ and a distance of $5 \mathrm{~m}$ from the center of each plot. Each of the sub-plots consists of two circular, concentric, sized 25 and $10 \mathrm{~m}^{2}$ plots.

The diameter at breast height $(\mathrm{D})$ and height $(\mathrm{H})$ of all stems were measured in each sampling plot and their average values $\left(\mathrm{D}_{\mathrm{av}}, \mathrm{H}_{\mathrm{av}}\right)$ were calculated for each plot. Only individuals with the diameter equal or larger than $7 \mathrm{~cm}$ were measured. A height of the highest oak tree in each plot $\left(\mathrm{H}_{\max }\right)$ was used to assess the site productivity analogically to site index, a measurement commonly used in forestry (Skovsgaard and Vanclay 2008). We consider it only as a proxy, since exact age of the trees is unknown. The number of stems growing out of one stool (currently still joined or with evidence of connection) was noted. The volume ( $v o l$ ), the basal area (BA), as well as stem density (dens) were calculated. The height of all saplings (defined as: individuals higher than $50 \mathrm{~cm}$ with a diameter less than $7 \mathrm{~cm}$ ) were measured in each sub-plot, on circular sampling plots sized $25 \mathrm{~m}^{2}$. Inside the $25 \mathrm{~m}^{2}$ sub-plots the number of seedlings (individuals shorter than $50 \mathrm{~cm}$ high) was also counted in concentric sampling plots sized $10 \mathrm{~m}^{2}$. We also recorded whether any visible damage, caused by browsing, was present. The aggregate height (AH) of the saplings was calculated as an efficient measurement of both size and density of the saplings (Fei et al. 2006).

Slope inclination (slope) and aspect in each of the sampling plots were measured. The value of the heat load (HL) was calculated according to the method by McCune (2007). The cover of forest floor vegetation (cover) was assessed visually and expressed as a percentage value.

In the center of each sub-plot the depth of soil (depth) was measured by driving a steel rod. Samples of the soil, taken from upper layer $(\mathrm{ca} .5-15 \mathrm{~cm}$ ) were taken for the analysis of $\mathrm{pH}$, and percentage of coarse fragments (CF), defined as mineral particles with a diameter $>2 \mathrm{~mm}$. A hemispherical photograph of the canopy was taken in the center of each sub-plot at a height of $50 \mathrm{~cm}$ above the ground layer. The photographs were subsequently analyzed using WinScanopy 2003b software by Regent Instruments Inc. to evaluate the light conditions. The results were expressed as percentage of photosynthetic photon flux density under canopies (PPFD).

Half of plots (13 plots in "Grobla", 12 in "Lipa", 25 in sum) was randomly selected for soil chemical analysis and soil texture. Soil samples from these plots were taken for chemical analysis. The sample consisted of five sub-samples per plot, taken by pedological auger from upper soil layer, and mixed into one sample. In such dried and mixed samples the content of total nitrogen $(\mathrm{N})$, available phosphorus $(\mathrm{P})$, potassium $(\mathrm{K})$, calcium $(\mathrm{Ca})$, magnesium $(\mathrm{Mg})$ and organic carbon $(\mathrm{C})$ were analyzed. The $\mathrm{N}$ was determined by Kjehdal method, $P$ by spectrophotometer, $K$ by flame photometer, $\mathrm{Ca}$ by atomic emission spectrophotometer, $M g$ by atomic absorption spectrophotometer and $\mathrm{C}$ by titration method. $\mathrm{C} / \mathrm{N}$ ratio, as a surrogate for the mineralization rate (Janssen 1996), was also calculated. In these mixed samples the soil texture was 
analyzed by laser diffraction method. Calculated were: percentage content of sand (particle diameter 2-0.05 $\mathrm{mm})$, silt $(0.05-0.002 \mathrm{~mm})$ and clay $(<0.002 \mathrm{~mm})$.

Therefore, we obtained a set of data containing 50 samples with known stand structure (including seedlings and sapling) slope, HL and average values (three measurements per plot) of soil depth, $\mathrm{pH}, \mathrm{PPFD}, \mathrm{CF}$ and C. For half of those plots (25), soil nutrient content and percentage of fine particles are also known.

The data describing seedlings and saplings by species contain numerous zero values, therefore to assess the relation between those data and environmental variables we had to apply a non-parametric test. In order to keep a comparable power of statistical tests in whole examination we decided to use the non-parametric Sperman rank correlation test for the whole data set. The significance level of $\alpha$ error was set up at 0.05 (Legendre and Legendre 2012). Due to high mortality of one-year seedlings only older individuals were considered in the analysis.

\section{Results}

Soil in the examined reserves was shallow, acidic with relatively low amount of calcium. The percentage of coarse fragments in soils was high and the $\mathrm{C} / \mathrm{N}$ ratio was high, what may indicate low decomposition of organic matter. Most of the sites obtained high input of solar energy, expressed as HL, also the percentage of light reaching forest floor (PPFD) was relatively high (Table 1 ).

In these stands $Q$. petreaea (93\% of volume of living trees, standard deviation $11.8 \%$ ) clearly dominated, however in tree layer we found ten other species: Acer pseudoplatanus L, Betula pendula Roth., Carpinus betulus L., Cerasus avium (L.) Moench, Fagus sylvatica L., Fraxinus excelsior L, Pinus sylvestris L., Populus tremula L., Sorbus torminalis (L.) Crantz., Tilia cordata Mill. and Tilia platyphyllos Scop. The Sorbus torminalis trees were present only on three plots. The density of living stems was on average $1224 \mathrm{~N} / \mathrm{ha}$, varied in wide range: from 440 up to $2920 \mathrm{~N} / \mathrm{ha}$, standard deviation $469 \mathrm{~N} / \mathrm{ha}$ (Fig. 2). The stand volume of living stems was on average $235.9 \mathrm{~m}^{3} / \mathrm{ha}$, S.D. $-68.9 \mathrm{~m}^{3}$ / ha and varied in the range from 64.7 up to $369.8 \mathrm{~m}^{3} /$ ha. Basal area of living stems was on average 32.6 $\mathrm{m}^{2} /$ ha, S.D.- $6.6 \mathrm{~m}^{2} /$ ha (Fig. 2). The percentage of dead stems was relatively low: 2.0 in stem volume and $6.5 \%$ in stem number. On the studied plot, we found 10 living wild service trees and one dead. It give an average density of 0.8 living wild service trees per hectare.

There were single layered stands. The mean height $\left(\mathrm{H}_{\text {av }}\right)$ of living stems was on average $14.6 \mathrm{~m}$, S.D. $3.18 \mathrm{~m}$ and varied threefold in the range of 6.27 up to $21.55 \mathrm{~m}$ (Fig. 2). The mean diameter $\left(\mathrm{D}_{\mathrm{av}}\right)$ of living stems was on average $18.2 \mathrm{~cm}$, S.D. 3,0 cm and varied twofold in the range of 11.5 up to $26.4 \mathrm{~cm}$. The average percentage (in volume) of multi-stem individuals was $35 \%$ but on some the plots about three-quarter of trees was multi-stems. The average height of the highest oaks per plot was 19.1, SD $3.9 \mathrm{~m}$ and varied from 10.4 up to $27.7 \mathrm{~m}$.

We found ten species among saplings: Acer pseudoplatanus L, Carpinus betulus L., Crataegus monogyna Jacq., Cornus mas L., Corylus avellana L. Fraxinus excelsior L, Populus tremula L., Quercus petraea (Matt.) Liebl., Rosa sp., Sorbus aucuparia, L. em. Hedl., Tilia cordata Mill. The saplings were dominated by ash and maple, while the percentage of oak was only about $2 \%$ (Table 2 ). We did not find any saplings of wild service tree on sampling plots. Most saplings (77\%), among them all saplings of ash, were damaged by browsing.

Specimens of all tree and sapling species were present among seedlings, except Pinus sylvestris. Additionally we found seedlings of: Acer platanoides, L., Frangula alnus Mill., Prunus spinosa, L. and Sambucus nigra $\mathrm{L}$. The seedlings were dominated by oak (almost $70 \%$ of all seedlings, ca. 5,500 individuals). Percentage of the second most abundant species, hornbeam, was much lower $-12 \%$ (Table 2 ). The number of seedlings of rare species: wild service tree and wild cherry was very low -17 and 23 respectively, what gives about $0.3 \%$ each. The Sorbus torminalis seedlings were found on 9 plots. Almost one third of seedlings

Table 1 . The number of plots $(\mathrm{N})$, average value (average), range (range) and standard deviation (STD) environmental traits

\begin{tabular}{lrrcr}
\hline \multicolumn{1}{c}{ Traits } & N & Average & Range & \multicolumn{1}{c}{ STD } \\
\hline slope [ ${ }^{\circ}$ ) & 50 & 12.9 & $0.0-40.0$ & 11.3 \\
HL & 50 & 0.9 & $0.67-0.94$ & 0.1 \\
PPFD [\%] & 50 & 22.7 & $14.0-35.2$ & 4.2 \\
cover [\%] & 50 & 56 & $10-80$ & 15 \\
depth [cm] & 50 & 18.9 & $5.0-34.0$ & 7.8 \\
stone [\%] & 50 & 6.1 & $0.0-35.0$ & 7.7 \\
pH & 50 & 4.2 & $3.3-5.1$ & 0.3 \\
$\mathrm{CF}[\%]$ & 50 & 44.4 & $9.5-81.9$ & 22.2 \\
$\mathrm{P}[\mathrm{mg} / 100 \mathrm{~g}]$ & 25 & 1.9 & $0.1-7.9$ & 1.9 \\
$\mathrm{~K}[\mathrm{mg} / 100 \mathrm{~g}]$ & 25 & 15.6 & $6.4-29.0$ & 7.1 \\
$\mathrm{Mg}[\mathrm{mg} / 100 \mathrm{~g}]$ & 25 & 13.8 & $2.2-31.0$ & 8.2 \\
$\mathrm{Ca}[\mathrm{mg} / 100 \mathrm{~g}]$ & 25 & 171.8 & $11.0-358.0$ & 86.7 \\
$\mathrm{~N}[\%]$ & 25 & 0.4 & $0.1-0.9$ & 0.2 \\
$\mathrm{C}[\%]$ & 25 & 6.9 & $2.5-16.1$ & 3.3 \\
$\mathrm{C} / \mathrm{N}$ & 25 & 20.22 & $13.3-58.6$ & 8.6 \\
sand [\%] & 25 & 45.5 & $31.0-75.0$ & 13.7 \\
silt [\%] & 25 & 50.0 & $23.0-64.0$ & 12.7 \\
clay [\%] & 25 & 4.6 & $2.0-6.0$ & 1.3 \\
\hline
\end{tabular}



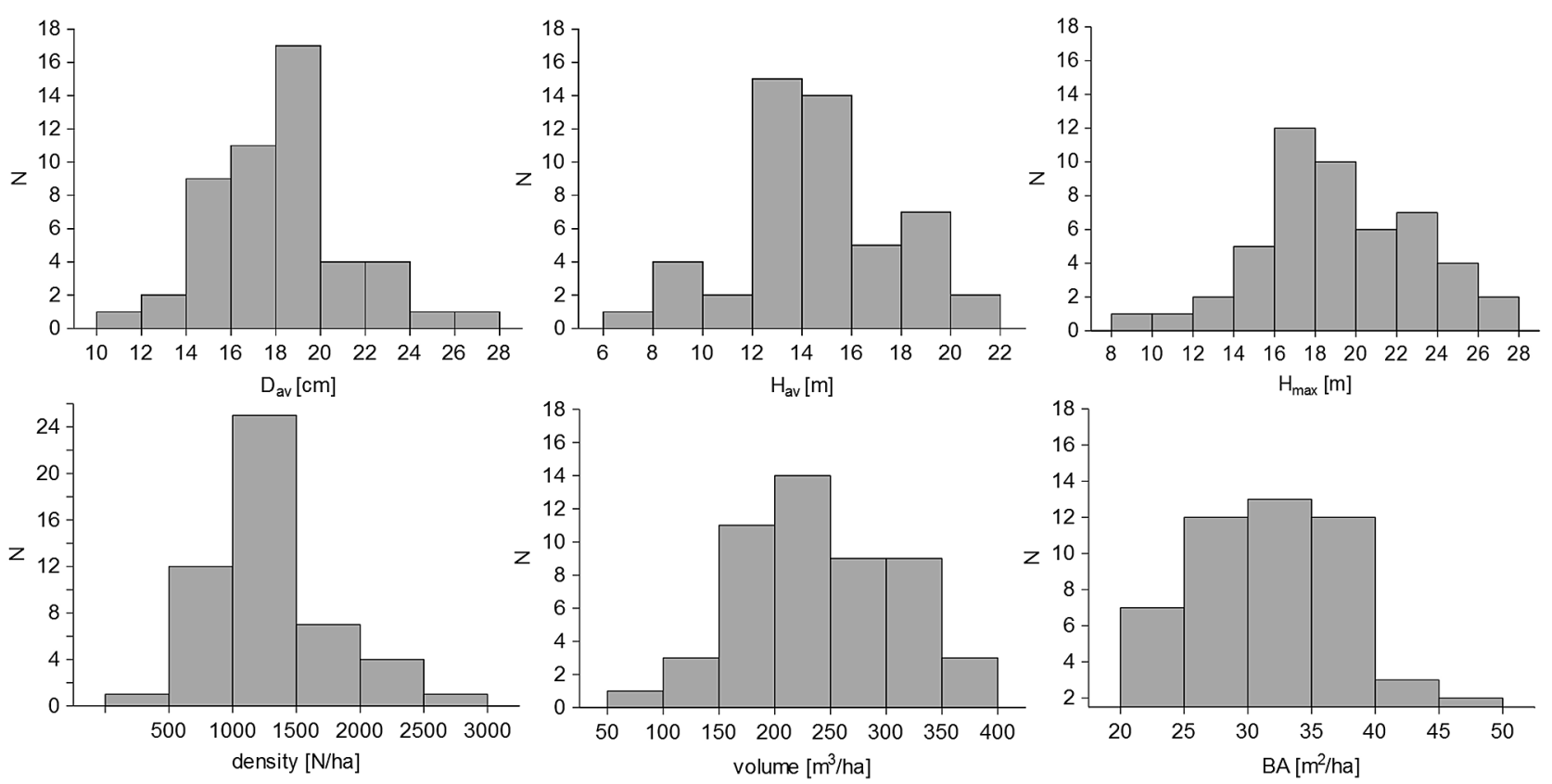

Fig. 2. Distributions of stem and stand parameters: average diameter (Dav), average height (Hav), maximal height (Hmax), stand density, volume and basal area (BA). $\mathrm{N}$ - the number of plots. Note another scale on vertical axe on graph showing distribution of stems density

was browsed. We observed that browsing was correlated with height of the seedlings: usually short ones (up to ca. $15 \mathrm{~cm}$ ) were not browsed, while taller ones very frequently.

Stems density was the highest on steep slopes with numerous rocky outcrops (Table 3 ). The average stems size decreased with slope and increasing percentage of $C F$ and $C$ in soils. The maximum height of trees also decreased with HL, CF, C, and percentage of sand in soil, while increased when the percentage of fine particles was higher (Fig. 3). On steep slopes the percentage of multi-stem individuals was also the highest. The mortality (expressed as a percentage of dead standing stems) was also correlated with slope, stone runs, $\mathrm{C}$ and $\mathrm{HL}$, while the stand volume was higher on less acidic soils and with smaller percentage of coarse fragments in soils (Table 3 ). We did not find any significant correlation between volume of trees by species and environmental variables.

The seedlings were more numerous on less acidic soils with lower content of C (Table 4). The seedlings generally avoided sites with high potential heat load (HL) and high access of light to forest floor (PPFD). The effect of environment was notably visible in case

Table 2. Structure of regeneration (seedlings and saplings) by species. Abbreviation: AP - Acer pseudoplatanus, CA - Cerasus avium, CB - Carpinus betulus, CM - Crataegus monogyna, FE - Fraxinus excelsior, QP - Quercus petraea, ST - Sorbus torminalis, Tsp - Tilia cordata and T. platyphyllos, other - other species of trees and shrubs (all species listed in Results)

\begin{tabular}{lcccccccccc}
\hline & AP & CA & CB & CM & FE & QP & ST & Tsp & other & sum \\
\hline seedlings & & & & & & & & & \\
average density [N/ha] & 1193.32 & 160.00 & 7053.26 & 86.67 & 6073.27 & 38612.95 & 146.67 & 2593.31 & 1013.3 & 56846.00 \\
percentage in density [\%] & 2.10 & 0.28 & 12.41 & 0.15 & 10.68 & 67.93 & 0.26 & 4.56 & 1.63 & 100.00 \\
percentage of browsed [\%] & 43.9 & 66.7 & 14.1 & 76.9 & 10.7 & 38.3 & 0.0 & 1.8 & 56.3 & 31.1 \\
percentage of one year seedlings [\%] & 11.7 & 4.2 & 69.1 & 7.7 & 86.9 & 4.2 & 22.7 & 95.1 & 6.6 & 25.5 \\
percentage of plot [\%] & 64 & 20 & 62 & 16 & 44 & 98 & 20 & 46 & 58 & 98 \\
\hline saplings & & & & & & & & & \\
average sum of height [m/ha] & 413.5 & 0.0 & 248.3 & 90.8 & 348.0 & 28.3 & 0.0 & 86.1 & 245.9 & 1370.1 \\
percentage in sum of height [\%] & 30.18 & 0 & 18.12 & 6.63 & 25.40 & 2.06 & 0 & 6.29 & 11.3 & 100 \\
average density [N/ha] & 146.7 & 0.0 & 181.3 & 42.7 & 197.3 & 42.7 & 0.0 & 61.3 & 130.7 & 759.9 \\
percentage of browsed [\%] & 52.7 & 0.0 & 89.0 & 31.3 & 100.0 & 100.0 & 0.0 & 100.0 & 38.7 & 77.7 \\
percentage of plot [\%] & 12 & 0 & 16 & 8 & 20 & 6 & 0 & 16 & 16 & 36 \\
\hline
\end{tabular}


Table 3. Sperman rank correlations between environmental variables, stand, and stem parameters. Only significant values $(p<0.05)$ of Spearman $\mathrm{r}$ values are shown. The results for $B A$, as correlated with $v o l$ are not shown, $\%$ dead in dens and $\%$ dead in $v o l$ - percentage of dead standing stems in stand density and volume, respectively. The abbreviations of names of environmental variables: $\mathrm{HL}$ - potential heat load, $\mathrm{CF}$ - percentage of coarse fragment in soil $\mathrm{C}$ - percentage content of organic carbon in soil

\begin{tabular}{|c|c|c|c|c|c|c|c|c|}
\hline & dens & $\begin{array}{l}\% \text { dead } \\
\text { in dens }\end{array}$ & vol & $\begin{array}{c}\% \text { dead } \\
\text { in vol }\end{array}$ & $\begin{array}{c}\% \text { clumped } \\
\text { trees }\end{array}$ & $\mathrm{D}_{\mathrm{av}}$ & $\mathrm{H}_{\mathrm{av}}$ & $\mathrm{H}_{\max }$ \\
\hline HL & & 0.364 & & 0.402 & & & & -0.296 \\
\hline slope & 0.667 & 0.562 & & 0.532 & 0.380 & -0.402 & -0.281 & \\
\hline stone & 0.347 & 0.300 & & 0.317 & & & & \\
\hline $\mathrm{CF}$ & & & -0.493 & & & -0.408 & -0.571 & -0.665 \\
\hline $\mathrm{pH}$ & & & -0.315 & & & & & \\
\hline $\mathrm{C}$ & & & & 0.331 & & & -0.320 & -0.281 \\
\hline sand & & & & & & & & -0.460 \\
\hline silt & & & & & & & & 0.494 \\
\hline
\end{tabular}

of density changes of seedlings of ash and wild service trees. Ash preferred less acidic, deeper soils with low content of organic carbon, where usually the availability of light was lower. To the contrary, the wild service tree seedlings were more abundant on shallow acid soils on slopes with high light availability (Table 4, Fig. 4). We did not find any direct relation-
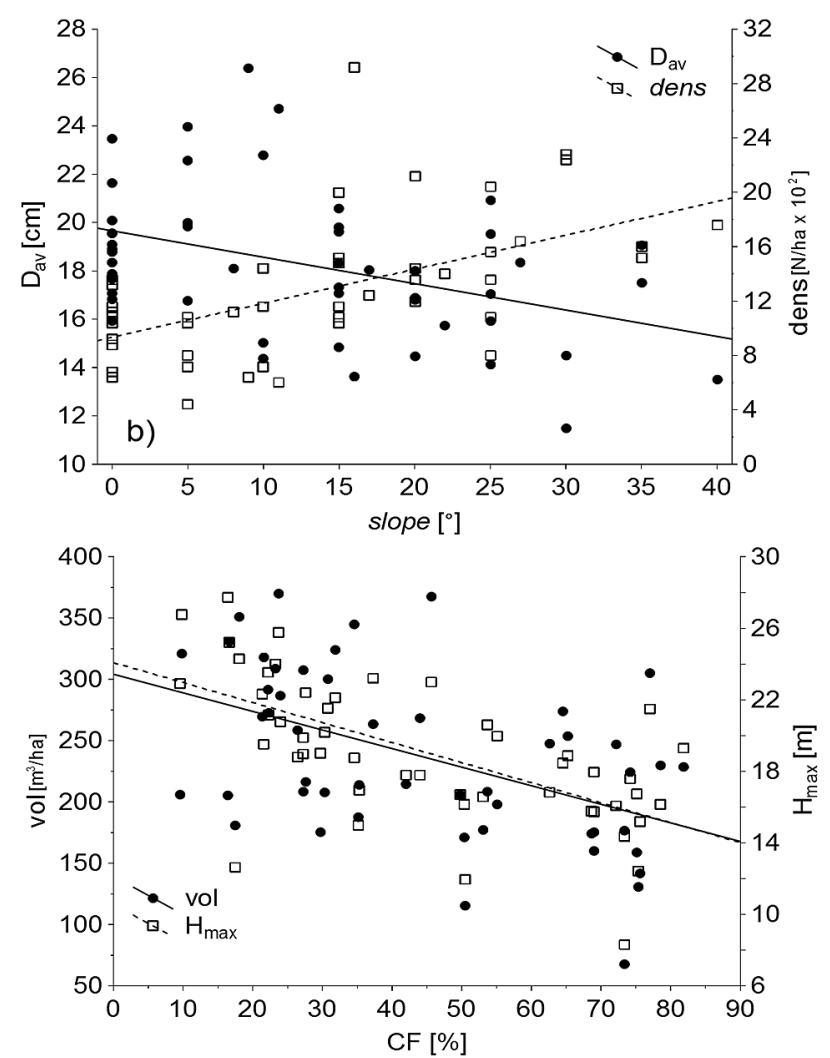

Fig. 3 Correlation between environmental traits (slope inclination-slope, percentage of coarse fragments in soil - CF and stand structure: average diameter $\left(D_{a v}\right)$, stem density (dens), stand volume (vol) and maximal height $\left(\mathrm{H}_{\max }\right)$ ship between percentage volume of given tree species in stand and seedlings density and sum of height of saplings of this species.

Table 4. Sperman rank correlations between sapling and seedlings by species and environmental variables. Only significant values $(p<0.05)$ of Spearman $r$ values are shown. Abbreviation: AP - Acer pseudoplatanus, FE - Fraxinus excelsior, QP - Quercus petraea, ST - Sorbus torminalis. The abbreviations of names of environmental variables: $\mathrm{C}$ - percentage of organic carbon in soil, PPFD- percentage of photosynthetic photon flux density, HL - potential heat load

\begin{tabular}{lccccc}
\hline & AP & FE & QP & ST & overall \\
\hline pH & & 0.386 & & -0.379 & 0.333 \\
C & & -0.405 & -0.334 & & -0.439 \\
depth & & 0.359 & & -0.327 & \\
PPFD & & -0.287 & -0.280 & 0.310 & -0.295 \\
HL & -0.308 & & -0.299 & & -0.351 \\
slope & & & & 0.300 & \\
\hline
\end{tabular}

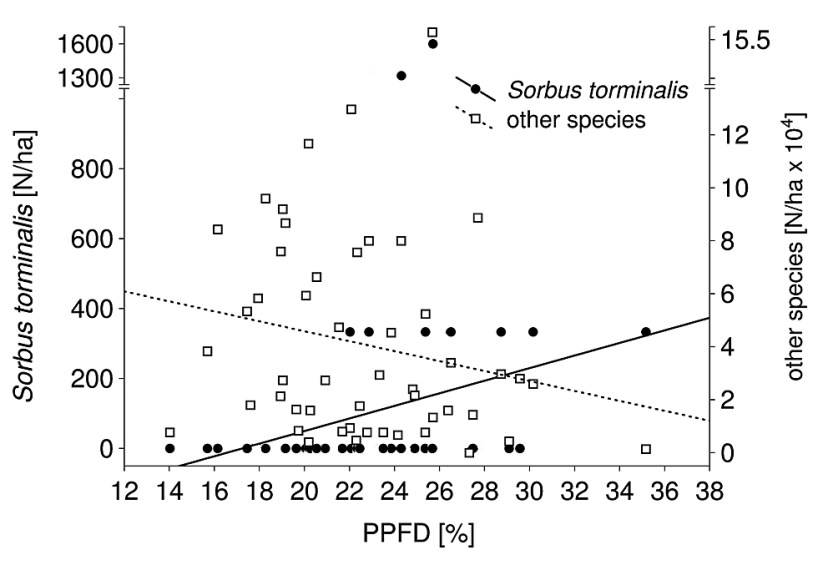

Fig. 4. Correlations between percentage of photosynthetic photon flux density (PPFD) and density of Sorbus torminalis seedlings as well as seedlings of remaining species. Note break on vertical axes in graph 


\section{Discussion}

The complex land-relief in studied sites results in a considerable gradient of soil conditions. Results show that the most unfavorable conditions for tree growth were in sites with coarse textured soils. Water holding capacity of such soils is low and the thin soil layer may dry out completely in spite of relatively abundant precipitation (Schoenholtz et all 2000, Ellenberg 2009, Bergès and Balandier 2010). Moreover, the southern exposition is related to a relatively high heat load, what causes excessively increased evaporation of soil. Such diversification in local topography is claimed to cause considerable diversification of trees growth, even on small areas with uniform climate (Oberhuber and Kofler 2000). In case of Sorbus torminalis its low growth in sites with relatively high precipitation is also attributed to shallow soils, with low water holding capacity (Rasmussen 2007). The effect of nutrient content on stand volume and stem size was negligible. Also the correlation of $\mathrm{pH}$ with trees and stand traits was weaker than correlations with soil texture descriptor. Thus, the water relations masked the effect of chemical properties of soils in studied stands.

The relation of land relief and soil properties with stand parameters is not exclusively direct. The correlations of stem density, percentage of multi-stem individuals and slope inclinations are also the results of past management decisions. Conversion of coppice stand was the most difficult in slopes, simultaneously the financial profit in such sites was expected to be the lowest. Consequently, stands on more productive sites were most often converted (Szymura 2012). Thus, the correlation of decreasing average stand height and increasing stems density with slope was strengthen by past management decisions, i.e. maintaining of coppicing. However, results of analysis of soil properties indicate that sites with rather visual attributes of low productivity, as steep slopes and places with stone runs or rocky outcrop, had been chosen for conversion more often than truly less productive sites with coarse soil texture.

The variability in site productivity and correlated with it differentiation in forest management practices, result in a significant variability of stand structure traits. The average values of stem density and BA were similar to abandoned oak - wild service - and beech coppices with standard stands in Bavaria, aged 90-140, where the average tree density was $1042 \mathrm{~N} /$ ha and $B A 23.22 \mathrm{~m}^{2} /$ ha (Müller et al. 2000). Similar parameters for oak-hornbeam coppice with standards, under continuous conversion into high forest, were found in Belgium where the average density was $1054 \mathrm{~N} / \mathrm{ha}$, stand volume $215 \mathrm{~m}^{3} / \mathrm{ha}$ and basal area $24.8 \mathrm{~m}^{2} /$ ha (André and Ponette 2003). The stem density in sampling plots placed on the slope, with the highest percentage of still clustered stems, corresponded well to values found in an oak-wild service stand in Thuringia, abandoned in the 1950s and previously managed as a coppice for firewood production, where the density of stems was 2459 trees/ha (Getzin et al. 2008).

In the studied stands the number of seedlings decreased with light availability (Table 4, Fig 4), thus differs from a pattern usual in forests ecosystems where, in general, it is observed that seedlings react positively to increased light availability (Modry et all 2004). It is related to two factors: firstly, the overall light condition was favorable for regeneration of most of the tree species (average PPFD ca. 23\%), thus the light was not the limiting factor. Secondly, since the PPFD was positively correlated with HL, the decrease of seedlings number with PPFD was interpreted by us as an effect of soil dryness. Alternatively, for some shade tolerant tree species, effect of indirect facilitation is observed, where seedlings are more abundant in shade due to competitive exclusion of herbs in better light condition (Pages and Michalet 2003, Filipiak et all 2005). However, in this study we did not observe any correlation between cover of forest floor vegetation and seedlings density. Therefore, this hypothesis should be excluded. Correlations of seedlings density by species with environmental variables clearly show the otherness of regeneration niche of wild service tree, in comparison to niches of remaining tree species. Wild service tree is a low competitive species, with high demand for nutrient content and temperature, but one of the most drought tolerant tree species in Central Europe (Rasmussen and Kollman 2004, Paganová 2007, Maděra et all 2013). It is considered as a relic of warmer climatic period on the northern limits of its range in Central Europe. In subsequent cooler climatic periods, as low competitive species, it has persisted only on poor sites, too dry for most dominant tree species (Rasmussen and Kollmann 2004). In studied forests the wild service tree seedlings clearly reacted on the level of light. Although the competition seems to be another factor influencing wild service tree regeneration, because its seedlings were more abundant on shallow and acidic soils, where seedlings of other species were less abundant. Altogether it led to presence of wild service tree seedlings only on the most exposed sites, where environment is too harsh for regeneration of other tree species. In studied stands such sites perform a function of regeneration niche for this species. On flatter areas, with deeper soils, such function is performed by edges of the stands (Rasmussen and Kollman 2004, Maděra et all 2012). Since we did not find any correlation between environmental variables and distribution of adult individuals, and regeneration niche of Sorbus torminalis is related to insolated sites with shallow soils, it gives a credence to hypoth- 
esis that in the studied stands this species was intentionally planted in more productive sites with deeper soil (Szymura 2012).

Considered above environmental factors controlling seedlings abundance became insignificant with increasing size/age of young individuals. It emerged in lack of correlations between saplings sum of height, their density, and environmental variables. The observations indicate that it is an effect of continuous, strong browsing, which became the factor controlling natural regeneration of trees. On the studied area (Jawor district of State Forest Holding) density of game; red deer (Cervus elaphus), roe deer (Capreolus capreolus) and mouflon (Ovis ammon) is high and could hamper natural regeneration of trees (Szymura et all 2010). Such effect of browsing has been reported in other field studies (Cermák and Mrkva 2006, Collet et all 2008) and it is considered as preventing natural regeneration of Sorbus torminalis (Bednorz 2009, Bednorz et all 2012, Maděra et all 2012).

From the nature conservation's point of view, the observation suggests that to ensure the continuity of presence of Sorbus torminalis, some protection against browsing is necessary. Such protection should allow to survive this species in exposed sites, on shallow soils which are natural refugees for this species in the northern limit of its range. However, it is not clear that only protection against browsing will allow to maintain Sorbus torminalis even on more productive sites where it is a key component of priority in European habitat of Euro-Siberian steppic woods, according to Natura 2000 system. To retain this vegetation type perhaps some diminishing of competitive influence of other tree species in canopy layer is needed. Restoration of coppice management or substantial, persistent and repeated thinning seem to be a promising example of protecting the wild service tree (Müller et all 2000, Maděra et all 2012).

\section{Acknowledgements}

Thanks for two anonymous reviewers for their comments, whose help improved the manuscript. The study was supported by Wrocław University grant.

\section{References}

André F., Ponette Q. 2003. Comparison of biomass and nutrient content between oak (Quercus petraea) and hornbeam (Carpinus betulus) trees in a coppice-with-standards stand in Chimay (Belgium). Annales of Forestry Science 60: 489-502.
Bednorz L. 2007. The wild service tree Sorbus torminalis (L.) Crantz in plant communities of Poland. Dendrobiology 57: 49-54.

Bednorz L. 2009. Jak chronić jarzą brekinię (Sorbus torminalis) w polskich lasach? Sylwan 153: 354360.

Bednorz L., Kaźmierczak K., Kaczmarek L. 2012. Analyses of spatial structure and selected measures of growth of Sorbus torminalis in Forest District Jamy (northern Poland). Dendrobiology 67: 59-65.

Bergès L., Balandier P. 2010. Revisiting the use of soil water budget assessment to predict site productivity of sessile oak (Quercus petraea Liebl.) in the perspective of climate change. European Journal of Forest Research 129: 199-208.

Cermák P., Mrkva R. 2006. Effects of game on the condition and development of natural regeneration in the Vrapac National Nature Reserve (Litovelské Pomoraví). Journal of Forest Science 52: 329-336.

Chytrý M., Danihelka J. 1993. Long-term changes in the field layer of oak and oak-hornbeam forests under the impact of deer and mouflon. Folia Geobotanica et Phytotaxonomica 28: 225-245.

Collet C., Piboule A., Leroy O., Frochot H. 2008. Advance Fagus sylvatica and Acer pseudoplatanus seedlings dominate tree regeneration in a mixed broadleaved former coppice-with-standards forest. Forestry 81: 135-150.

Decocq G., Aubert M., Dupont F., Bardat J., Wattez-Franger A., Saguez R., Foucault de B., Alard D., Delelis-Dusollier A. 2005. Silviculture-driven vegetation change in a European temperate deciduous forest. Annals of Forest Science 62: 313-323.

Ellenberg H. 2009. Vegetation ecology of central Europe, Ed. 4. Cambridge University Press, Cambridge.

Filipiak M., Iszkuło G., Korybo J. 2005. Relation between photosynthetic photon flux density (PPFD) and growth of silver fir (Abies alba Mill.) seedlings in a forest stand dominated by spruce [Picea albies (L.)H.Karst.] in the Sudety Mts (SW Poland). Polish Journal of Ecology 53: 177-184.

Fei S., Gould P. J., Steiner K. C., Finley J. C. 2006. Aggregate height a composite measure of stand density for tree seedling populations. Forest Ecology and Management 223: 336-341.

Getzin S., Wiegand K., Schumacher J., Gougeon F.A. 2008. Scale-dependent competition at the stand level assessed from crown areas. Forest Ecology and Management 255: 2478-2485.

Hédl R., Kopecký M., Komárek J. 2010. Half a century of succession in a temperate oakwood: from species-rich community to mesic forest. Diversity and Distribution. 16: 267-276. 
Hofmeister J., Martin Mihaljevič M., Hošek J. 2004. The spread of ash (Fraxinus excelsior) in some European oak forests: an effect of nitrogen deposition or successional change? Forest Ecology and Management 203: 35-47.

Janssen B.H. 1996. Nitrogen mineralization in relation to $\mathrm{C}: \mathrm{N}$ ratio and decomposability of organic materials. Plant and Soil 181:39-45.

Kwiatkowski P. 2001. Zbiorowiska leśne Pogórza Złotoryjskiego. Fragmenta Floristica et Geobotanica 8: 178-218.

Kwiatkowski P. 2003. Podgórska ciepłolubna dąbrowa brekiniowa Sorbo torminalis- Quercetum na Pogórzu Złotoryjskim. Fragmenta Floristica et Geobotanica 10: 175-193.

Legendre P., Legendre L. 2012. Numerical Ecology, 3th edition. Elsevier.

McCune B. 2007. Improved estimates of incident radiation and heat load using non-parametric regression against topographic variables. Journal of Vegetation Science 18: 751-754.

Maděra P., Kohoutek M., Šenfeldr M., Řepka R. 2012. The population structure and regeneration of Sorbus torminalis in Hádecká planinka National Nature Reserve (Czech Republic). Dendrobiology 68: 63-68.

Maděra P., Tichá S., Řepka R. 2013. Distribution and ecological requirements of Sorbus torminalis (L.) Crantz in the Czech Republic. Dendrobiology 69: $59-68$.

Matthews J.D. 2001. Silvicultural systems. Oxford University Press.

Modry M., Hubeny D., Rejsek K. 2004. Differential response of naturally regenerated European shade tolerant tree species to soil type and light availability. Forest Ecology and Management 188: 185-195.

Müller S. von, Ammer C., Nüsslein S. 2000. Analyses of stand structure as a tool for silvicultural decisions - a case study in Quercus petrea - Sorbus torminalis stand. Forstwissenschaft Centralblatt 119: 32-42.

Oberhuber W., Kofler W. 2000. Topographic influences on radial growth of Scots pine (Pinus sylvestris L.) at small spatial scales. Plant Ecology 146: 231-240.

Paganová V. 2007. Ecology and distribution of Sorbus torminalis (L.) Crantz. in Slovakia. Horticular Science 34: 138-151.

Pages J.P., Michalet R. 2003. A test of the indirect facilitation model in a temperate hardwood forest of the northern French Alps. Journal of Ecology 91: 932-940.

Rasmussen K.K., Kollmann J. 2004. Poor sexual reproduction on the distribution limit of the rare tree Sorbus torminalis. Acta Oecologica 25: 211218.

Rasmussen K.K. 2007. Dendroecological analysis of a rare sub-canopy tree: Effects of climate, latitude, habitat conditions and forest history. Dendrochronologia 25: 3-17.

Schoenholtz S.H., Miegroet H.V., Burger J.A. 2000. A review of chemical and physical properties as indicators of forest soil quality: challenges and opportunities. Forest Ecology and Management 138: 335-356.

Skovsgaard J.P., Vanclay J.K. 2008. Forest site productivity: a review of the evolution of dendrometric concepts for even-aged stands. Forestry 81: 13-31.

Szymura T.H., Buszczak M., Szymura M. 2010. Structure and dynamics of a mature tree stand in submontane alluvial forest of Carici ramotae-Fraxinetum in the Sudety Mts foothills (Lower Silesia, Poland). Dendrobiology 63: 43-51.

Szymura T.H., Szymura M. 2011. Soil properties and light availability determine species richness and vegetation diversity in an overgrown coppice oak stand. Polish Journal of Ecology 59: 523-533.

Szymura T.H. 2012. How does recent vegetation reflect previous systems of forest management ? Polish Journal of Ecology 60: 859-862.

Szymura T.H., Szymura M. 2013. Spatial variability more influential than soil $\mathrm{pH}$ and land relief on thermophilous vegetation in overgrown coppice oak forests. Acta Societatis Botanicorum Poloniae 82: 5-11.

Van Calster H., Baeten L., De Schrijver A., De Keersmaeker L., Rogister J.E., Verheyen K., Hermy M. 2007. Management driven changes (1967-2005) in soil acidity and the understorey plant community following conversion of a coppice-with-standards forest. Forest Ecology and Management 241: 258-271.

Verheyen K., Baeten L., De Frenne P., Bernhardt-Römermann M., Brunet J., Cornelis J., Decocq G., Dierschke H., Eriksson O., Hédl R., Heinken T., Hermy M., Hommel P., Kirby K., Naaf T., Peterken G., Petř́k P., Pfadenhauer J., Van Calster H., Walther G-R., Wulf M., Verstraeten G. 2012. Driving factors behind the eutrophication signal in understorey plant communities of deciduous temperate forests. Journal of Ecology 100: 352-365. 